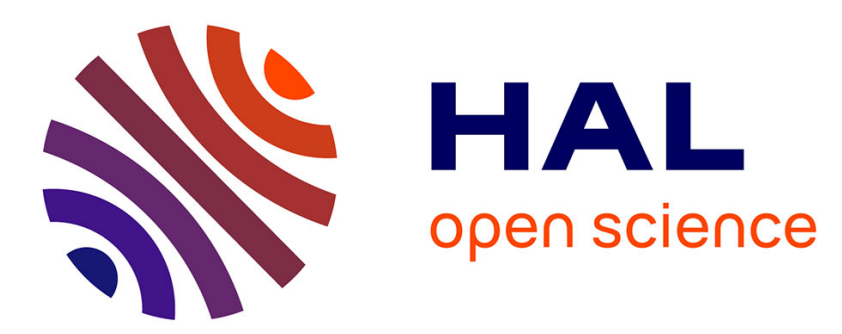

\title{
Language and Intergroup Contact: Investigating the Impact of Bilingual Instruction on Children's Intergroup Attitudes
}

Stephen C. Wright, Linda R. Tropp

\section{- To cite this version:}

Stephen C. Wright, Linda R. Tropp. Language and Intergroup Contact: Investigating the Impact of Bilingual Instruction on Children's Intergroup Attitudes. Group Processes and Intergroup Relations, 2005, 8 (3), pp.309-328. 10.1177/1368430205053945 . hal-00571610

\section{HAL Id: hal-00571610 \\ https://hal.science/hal-00571610}

Submitted on 1 Mar 2011

HAL is a multi-disciplinary open access archive for the deposit and dissemination of scientific research documents, whether they are published or not. The documents may come from teaching and research institutions in France or abroad, or from public or private research centers.
L'archive ouverte pluridisciplinaire HAL, est destinée au dépôt et à la diffusion de documents scientifiques de niveau recherche, publiés ou non, émanant des établissements d'enseignement et de recherche français ou étrangers, des laboratoires publics ou privés. 


\title{
Language and Intergroup Contact: Investigating the Impact of Bilingual Instruction on Children's Intergroup Attitudes
}

\author{
Stephen C. Wright \\ Simon Fraser University \\ Linda R. Tropp \\ Boston College
}

This study examined the impact of bilingual versus English-only instruction on the intergroup attitudes of White, English-speaking children in kindergarten through second grade.

Replicating prior research, White children generally showed a clear preference toward the ingroup in terms of positive evaluations, friendship preference, and perceived similarity to the self. However, all three effects were significantly smaller among children who were in classrooms with a significant amount of Spanish instruction (i.e. bilingual classes). The smaller preference for the ingroup over the outgroup found in bilingual classes resulted from higher evaluations of, greater selection of friends among, and greater perceived similarity to Latino targets, and not from changes in preference for White ingroup targets. Furthermore, comparisons with English-only classes that had substantial Latino representation shows that the positive impact of bilingual instruction can be only partially explained by the greater representation of Latino children in bilingual classes. Finally, these positive patterns of intergroup attitudes found in bilingual classes were not associated with any negative effects on White children's personal self-evaluation.

KEYWORDS bilingual education, children, intergroup attitudes, intergroup contact, prejudice

Bilingual education is under vigorous attack. In the state of California, a popular initiative 'outlawed' most forms of bilingual education and mandated that all non-English speaking children be quickly 'mainstreamed' into standard English-only classes. Similar initiatives are

\section{Author's note}

Address correspondence to Stephen C. Wright, Psychology Department, Simon Fraser University, Burnaby, BC, V5A 1S6, Canada [email: scwright@sfu.ca] 
being considered or have been passed in Arizona, Massachusetts, and several other states, and new federal policies restrict the amount of heritage language education children can receive (Slavin \& Cheung, 2003). These initiatives come at a time when more than $20 \%$ of all US students come from homes where English is not the primary language (Van Hook \& Fix, 2000). Thus, just as American public schools are facing unprecedented linguistic and cultural diversity, public support for instruction in languages other than English appears to be in retreat.

The public debate on bilingual education has paralleled an equally contentious academic debate (see Hakuta, Butler, \& Witt, 2000). The argument is complicated by the wide range of models of 'bilingual education' and the multitude of specific programs based on each model. However, despite critiques, most research-based reviews conclude that the important benefits of bilingual education outweigh the potential costs (see Crawford, 1989; Cummins, 1989; Genesee, 1987; Greene, 1997; Hakuta, 1986; Slavin \& Cheung, 2003; Willig, 1985; WongFillmore \& Valdez, 1986). Indeed, in terms of the experiences of non-English speaking children, the data suggest that current efforts to reduce minority-language instruction are unfortunate and misguided.

At the same time, since bilingual education has been viewed primarily as a compensatory measure for educating non-English speakers (see Brisk, 1998), most discussions have examined its impact on the academic achievement and language acquisition of minority language children (e.g. Edwards, 1977; Genesee, Rogers, \& Holobow, 1983; Hakuta et al., 2000; Parker, 1978; Slavin \& Cheung, 2003; Sue \& Padilla, 1986; Wright, Taylor, \& Macarthur, 2000). By contrast, the social outcomes of bilingual instruction have been sorely understudied (see Barker et al., 2001; Genesee \& Gándara, 1999; Lambert \& Cazabon, 1994; Noels, Pon, \& Clément, 1996; Wright \& Taylor, 1995), and little is known regarding how bilingual instruction influences children's attitudes toward different language groups (see Aboud \& Levy, $2000)$. But as research in the tradition of this special issue has shown, the connections between language and intergroup relations are numerous and important. Language represents much more than a medium of communication, serving also as a key marker of social identity and as a determinant of intergroup behavior. Thus, more research is needed to understand how participation in bilingual instruction may affect intergroup attitudes toward members of other language groups.

Moreover, since bilingual education has been regarded as an issue that is mostly relevant to the education of minority language students, very little attention has been paid to its impact on majority language children (see Lambert, Genesee, Holobow, \& Chartrand, 1993; Lambert \& Tucker, 1972 for notable exceptions). The present research focuses directly on these two understudied areas by considering the effects of Spanish/English bilingual instruction versus English-only instruction on the intergroup attitudes of White, English-speaking children. ${ }^{1}$

We examine these issues in the context of children's earliest school experiences-kindergarten through Grade 2. Obviously, children at these grade levels have had the least exposure to prior classroom contexts that could influence their responses to the present classroom setting. These are also the ages at which children tend to become aware of ethnic differences (Aboud, 1988; Katz, 1983), and begin to form enduring perceptions of, and attitudes toward, members of different ethnic groups (Foster, 1994; Ramsey, 1987). Moreover, it appears that young children are well aware of linguistic differences and their importance in determining group membership (see Aboud, 1977). Thus, it is surprising that the role of language as a marker of group membership has remained understudied in the research literature on children's intergroup attitudes.

Generally, research on the intergroup attitudes of young children suggests that White children typically express positive attitudes toward their ethnic ingroup (Weiland \& Coughlin, 1979; Williams \& Morland, 1976), while rarely showing equally positive attitudes toward other racial or ethnic groups (Doyle \& Aboud, 1995; Katz, 1983). In some instances, 
White children may even demonstrate a clear rejection of children from racial or ethnic outgroups, while maintaining positive attitudes toward members of the White ingroup (Asher \& Allen, 1969; Corenblum \& Wilson, 1982). These initial intergroup perceptions can have an enduring impact on children's future attitudes, and it may become increasingly difficult to influence these attitudes as children grow older (Banks, 1995). Thus, children who are just forming intergroup attitudes may be most susceptible to influences of the educational environment, such as the language of instruction.

Considerable evidence shows that organizational structures and practices in school can significantly influence children's intergroup attitudes (Damico, Bell-Nathaniel, \& Green, 1981; Khmelkov \& Hallinan, 1999). Still, there is virtually no published research investigating how bilingual instruction affects children's intergroup attitudes. ${ }^{2}$ A possible explanation for the lack of attention to language as a variable affecting intergroup attitudes might be the traditional focus on racial differences, such as the extensive body of research regarding the effects of school desegregation on relations between Black and White children (see Schofield, 1989; Stephan \& Rosenfield, 1978). However, when one considers relations between White and Latino (or other immigrant) children, language becomes another key marker of group membership (Gudykunst \& Schmidt, 1987; Heller, 1987).

\section{Research on intergroup contact and the potential role of language}

Like much of the research on intergroup attitudes in schools, our analysis of the impact of bilingual instruction is guided by the Contact Hypothesis. Allport's (1954) formulation of the hypothesis proposes that contact between members of different groups can, under a specified set of conditions, lead to improved attitudes toward the outgroup as a whole. Much of the literature on intergroup contact in schools has provided support for the hypothesis and has highlighted the importance of Allport's 'optimal conditions' for enhancing positive intergroup attitudes (see Miller \& Brewer, 1984; Pettigrew, 1998; Pettigrew \& Tropp, 2005; Schofield, 1995 for reviews). Specifically, Allport proposed that contact should be structured so that: (a) members of the two groups hold equal status during the interaction; (b) it promotes cooperative interdependence between the members of the two groups; and (c) relevant authorities support the intergroup contact. We propose that the language of instruction can significantly contribute to establishing these important conditions within the classroom context.

\section{Equal status}

Given that language is a primary marker of group membership, the perceived status of each group's language will be inherently linked to the group's broader status (see Giles, Bourhis, \& Taylor, 1977). If English is the sole language of instruction, children will likely grow to believe that acquiring the valuable knowledge and skills imparted in school requires English proficiency. This clearly places the English language and those who speak it in a higher status position than other languages and those who speak them. The perceived status of English speakers may be enhanced further if English speakers fill most of the school's high-status positions (e.g. teachers, principals). English-only instruction can also give Englishspeaking students greater access to educational materials and to the teacher, from whom they can make more sophisticated requests, and receive more complex explanations. Thus, being an English speaker becomes associated with success and status, while speaking another language is not. In sum, English-only instruction suggests, either directly or subtly, that English speakers hold superior status within the classroom relative to members of other language groups.

In contrast, bilingual instruction can provide a clear affirmation of the value and status of the relevant minority language (Cummins, 1989; Lambert \& Cazabon, 1994). Bilingual instruction also establishes a direct connection between the teacher and both language groups, while equalizing their access to classroom resources (Parker, 1978). 


\section{Cooperative interdependence}

Cooperative interdependence has also been proposed as an important condition for successful intergroup contact, and considerable research supports this claim (Aronson \& Patnoe, 1997; Brewer \& Miller, 1984; Johnson, Johnson, \& Maruyama, 1984; Kagan, 1986; Schofield, 1989; Slavin \& Cooper, 1999). There is some evidence that the specific demands of bilingual instruction may lead teachers to make greater use of cooperative activities, even when the content of the lesson is not language (Lindholm, 1994). The degree that cooperative strategies are used in an Englishonly classroom, English speakers are likely to assume the role of tutors and non-English speakers are likely to become the recipients of their help. This dynamic not only highlights status inequalities between the groups, but also undermines the interdependent nature of cooperation that is essential for positive intergroup contact.

\section{Authority support}

Research has shown that support from authorities can make intergroup contact more acceptable, more frequent, and more effective at improving intergroup attitudes (see Pettigrew, 1998). In the classroom, the relevant authority is of course the teacher. The teacher's use of both languages is a direct and clear statement of his/her support for a multilingual context. Thus, instructional use of both languages may be the clearest possible statement that the authority is sanctioning positive, equal-status, cross-group interactions.

\section{New developments in contact research: Implications for bilingual instruction}

While there has been considerable support for Allport's proposed conditions (see Pettigrew, 1998), a recent resurgence of interest in the contact hypothesis has sparked a number of other advances (Brewer \& Brown, 1998; Gaertner \& Dovidio, 2000; Hewstone \& Brown, 1986; Miller \& Brewer, 1984; Pettigrew, 1998; Pettigrew \& Tropp, 2000). Among the new advances are two themes that appear particularly relevant to the present discussion.

\section{Cross-group friendships}

The first involves the kinds of contact experiences most likely to produce positive intergroup outcomes. Here, recent work has pointed to the particular importance of cross-group friendships for promoting positive changes in intergroup attitudes (Aboud, Mendelson, \& Purdy, 2003; McLaughlin-Volpe, Aron, Wright, \& Reis, 2000; Pettigrew, 1997; Wright, Aron, McLaughlin-Volpe, \& Ropp, 1997; Wright, Aron, \& Tropp, 2002; Wright, Brody, \& Aron, 2005; Wright \& Van der Zande, 1999). We propose that the classroom environment created by bilingual instruction may be more likely than English-only instruction to facilitate crossgroup friendships. Instruction in a second language may lead children to perceive greater similarity between themselves and members of the other language group (Genesee et al., 1983). There is ample evidence to suggest that perceptions of similarity are associated with greater propensities to form friendships (see Fehr, 1996). Thus, by learning a second language, White, English-speaking children may perceive greater similarity to their nonEnglish-speaking classmates, and this greater perceived similarity should increase children's willingness to develop friendships across ethnolinguistic boundaries (see Lambert \& Cazabon, 1994).

\section{Generalization of contact effects}

A second theme concerns how contact with an individual outgroup member generalizes to attitudes about the outgroup as a whole. Based on the social identity approach (Tajfel, 1978; Turner, Hogg, Oakes, Reicher, \& Wetherell, 1987), Hewstone \& Brown (1986) have argued that group memberships must be salient during contact for positive feelings toward individual outgroup members to generalize to the entire outgroup. There is now a growing consensus in the literature that, at some point, group memberships must become salient for interactions between individual group members to affect intergroup attitudes (see also Brewer \& Brown, 
1998; Brown \& Hewstone, 2005; Pettigrew, 1998; Rothbart \& John, 1985). Bilingual instruction may be able to facilitate positive interactions across group lines and increase feelings of interpersonal similarity while at the same time maintaining awareness of the ethnolinguistic distinctiveness of two language groups.

\section{The possible confound of classroom ethnic composition}

The numerical representation of White and non-White children in a classroom may also have a profound impact on the development of intergroup attitudes. Indeed, other work suggests that White children in more ethnically balanced classrooms tend to be more positive in their assessment of non-White children than those in White-only or predominantly White classes (see Aboud, 1988; Cohen, 1980; Kistner, Metzler, Gatlin, \& Risi, 1993; Schofield \& Sagar, 1977).

Typically, bilingual classes have more equal representations of White and non-White children than English-only classes. Thus, there is the possibility of confounding language of instruction with ethnic mix in the classroom. To address this issue, the present research includes two groups of English-only classrooms: those with balanced representations of White and Latino children and those with token or no representation of Latino children. Thus, we can consider the impact of interethnic contact alone versus contact supported by the use of the minority language.

\section{Language of instruction and self-evaluation}

Finally, we must also consider the potential effects of bilingual instruction on children's psychological well-being. The limited research on the impact of bilingual instruction on majority language children has shown no ill effects for these children (Lambert \& Cazabon, 1994; Lambert et al., 1993). However, some public opposition to bilingual education has focused on possible negative outcomes for White children, and specifically, on the possibility of poorer psychological adjustment. One important and well-studied aspect of adjustment in the school context concerns children's evaluations of themselves (Covington, 1989; Harter, 1986). The procedures used in the present study include a measure of children's self-evaluations, allowing for an investigation of the effects of language of instruction and classroom representation of Latino children on White children's views of themselves.

\section{Summary of research hypotheses}

Past research has shown that White children are generally more positive in their perceptions of ingroup targets than minority outgroup targets (e.g. Doyle \& Aboud, 1995). Thus, we hypothesized that White children would show general ingroup preference on measures of intergroup attitudes and perceived similarity. Specifically, we propose that White children will show ingroup bias by selecting more White than Latino targets in response to measures of (a) positive evaluations, (b) friendship preferences, and (c) perceived similarity (Hypothesis 1).

However, the extensive literature on intergroup contact would predict that White children in classrooms with a significant percentage of Latino students should hold more positive attitudes about Latinos. Therefore, we predict that White children in ethnically mixed classes (both bilingual and English-only) will show less bias in favor of White over Latino targets on measures of $(a)$ positive evaluations, (b) friendship preferences, and (c) perceived similarity, relative to White children in English-only classes with few or no Latino children (Hypothesis 2).

More importantly, however, we propose that bilingual instruction should create a more optimal contact setting and thus produce even more positive intergroup attitudes and greater perceptions of similarity to Latino targets. Thus, we further propose that White children in bilingual classes will show less bias in favor of White over Latino targets on measures of (a) positive evaluations, (b) friendship preferences, and (c) perceived similarity, relative to White children in ethnically mixed, English-only classes (Hypothesis 3). 
Finally, we expect that bilingual instruction would carry no cost to White children's evaluation of themselves. Therefore, we predict that White children in bilingual classes will report selfevaluations that are equally positive as those of children in English-only classes (Hypothesis 4).

\section{Method}

\section{Schools and sample}

Five Central California schools were selected because the student populations included primarily Latino and White children. The schools also varied in terms of socioeconomic status, geographic location (urban vs. rural), and the relative proportions of White and Latino students. Information about school population demographics was obtained in discussions with principals and teachers. Thus, these descriptions represent broad generalizations about each school.

Two schools were predominantly White (approximately $70 \%$ of the student population). These schools were located in upper middle class neighborhoods, and most Latino students were 'bussed' from poorer neighborhoods. Two other schools had more balanced enrollments of White and Latino students and were located in neighborhoods that were economically and ethnically mixed, with most children coming from working class and lower middle class families. The final school was predominantly Latino (over $75 \%$ of the student population). This school was in a farming community, and most of the White children were working class, while most of their Latino classmates were the children of farm workers (most with relatively permanent jobs in the area).

School principals approved access to kindergarten through second grade classrooms, pending approval of classroom teachers. Only one teacher declined. A total of 38 classrooms had adequate numbers of White children for use in the study. The response rate for parental approval ranged from $54 \%$ to $100 \%$ across classrooms. Non-participation resulted almost exclusively from children failing to return a parental permission form (less than $4 \%$ of parents who returned a form refused participation). The present study includes only responses from White children. ${ }^{3}$

The final sample of participants consisted of 351 White students (167 girls and 184 boys) from a total of 38 kindergarten $(n=130$, age $5-7$ years), first grade ( $n=110$, age $6-8$ years), and second grade ( $n=101$, age $7-9$ years $)$ classrooms. The children's mean age was 6.55 years.

\section{Classroom types}

Teachers of participating classes completed a short survey, in which they reported the amount of Spanish and English used in classroom instruction and the ethnic/linguistic heritage of each child in the class. Classrooms were then divided into three categories: (a) EthnicallyMixed Bilingual Instruction (25-88\% Latino students; 35-60\% instruction in Spanish), (b) Ethnically-Mixed English-Only Instruction (25-88\% Latino students; less than 10\% instruction in Spanish), and (c) PredominantlyWhite English-Only Instruction (less than 7\% Latino students; less than $10 \%$ instruction in Spanish). There were 109 students in 16 Ethnically-Mixed, Bilingual classes (Bilingual), 80 students in 12 Ethnically-Mixed, EnglishOnly classes (Mixed E-O), and 162 students in 10 Predominantly-White, English-Only classes (White E-O).

While the percentage of students in each type of classroom does vary somewhat from school to school, we have done everything possible to check that any effects of type of classroom cannot be accounted for by school. First, three of the five schools had all three types of classes -both upper middle class schools and one mixed neighborhood school. The remaining two schools had Mixed E-O and Bilingual classes (not White E-O classes). Thus, comparisons between bilingual instruction and Englishonly instruction can be made in all five schools.

It is also important to note that students are nested within classrooms. Thus, observations at the level of individual children may represent data points that are not entirely independent. The problem of non-independence can be addressed by using classroom as the unit of analysis. This, of course, greatly reduces the 
power of the test-reducing the cases from 351 to 38 . However, to demonstrate consistency in patterns of effects across levels of analysis, we will perform key analyses twice, first with child and then again with classroom as the unit of analysis.

\section{Materials}

Materials and procedures used here were adapted from Wright and Taylor (1995). Over 200 head-and-shoulders Polaroid photos of 5-7 year old Latino and White children were pretested using three Latino and three White adults. These six raters indicated the gender and ethnicity of the child in the photograph, and rated the photograph on three criteria, using 5-point Likert-type scales: (a) the clarity of the photograph, (b) the positivity of the child's facial expression, and (c) the child's physical attractiveness. The photographs were first screened such that only those photographs on which there was $100 \%$ agreement about gender and ethnicity were considered. Photographs were then matched on the remaining three criteria, to create same-gender Latino/White pairs that were near equivalent on each of the three ratings. Four (2 male and 2 female) Latino/ White matched pairs were combined to create a packet containing eight photographs. Six separate eight -picture testing packets were created.

\section{Procedures}

We ensured that children did not know any children in the photographs. ${ }^{4}$ Testing packets were randomly distributed to testers before each session, and each packet was used approximately equally in each school. Children were tested individually by a White female tester. Children were taken from their regular classes to a quiet place in the school. At the beginning of the session, the tester took a Polaroid photograph of the child and explained the activity as the photograph developed. The child's photograph was then added to the testing packet. All nine photographs (the child's and the eight target photographs) were shuffled and placed in random order in front of the child. The tester then asked the child to sort the nine photographs on a series of trials, using a standard request: 'Pick all the children who are and put them in this box, and leave all the children who are not on the table'. On each trial, the child was free to select all, some, or none of the nine photographs. Before each sorting trial, the tester would again shuffle the photographs and place them in a random order in front of the child.

The child was first asked to pick (1) the 'girls' and (2) the 'boys'. As children readily identify gender by this age (Cole \& Cole, 1993), these requests were used to ensure that the child understood the nature of the task.

\section{Dependent measures}

The child's selection and rejection of Latino and White targets in the subsequent sorting requests were used to assess: (a) Ingroup/Outgroup Evaluations, (b) Friendship Preferences, and (c) Perceived Similarity. In addition, the child's selection of his or her own picture in response to the six evaluation items was used as a measure of Personal Self-Evaluation.

Ingroup/outgroup evaluations The child was asked to sort the photographs in response to six evaluative items-selecting those: (1) who are good at lots of things; (2) who are smart; (3) who have lots of friends; (4) who are nice; (5) who are happy; and (6) who like school. For each trial, the number of Latino and the number of White targets were tabulated, creating separate ratings of ingroup evaluation and outgroup evaluation. In order to clarify the presentation of the results, the number of targets was converted into percentages of the possible total, such that the child's score on each trial could be $0 \%$ (no targets from that ethnic group selected), $25 \%$ (one of the four targets), $50 \%$ (two of the four), $75 \%$ (three of the four), or $100 \%$ (all targets from that ethnic group selected). Responses to the six sorting trials were combined to produce measures of Ingroup Evaluation $(\alpha=.80)$ and Outgroup Evaluation $(\alpha=.82)$.

Friendship preferences On a single sorting trial, children were asked to pick the targets they would like as best friends. Children's 
choices were tabulated separately for Latino and White targets and converted to percentages, creating two ratings that ranged from $0 \%$ (no targets from an ethnic group selected) to $100 \%$ (all four targets from an ethnic group selected).

Perceived similarity On a single sorting trial, children were asked to pick all the targets who are most like them. Children's choices were tabulated separately for Latino and White targets and converted to percentages, creating two ratings that ranged from $0 \%$ (no targets from an ethnic group selected) to $100 \%$ (all targets from an ethnic group selected).

Personal self-evaluation Since the packet of target photographs included the child's own picture, the child's self-evaluation could be calculated using the number of times he/she selected his/her own picture on the six evaluation sorting trials (good at lots of things, smart, lots of friends, nice, happy, and like school). These scores ranged from $0 \%$ (never selected his or her own picture) to $100 \%$ (selected his or her picture on all six trials).

\section{Supplementary measures}

Teacher survey After all the children in a class were tested, the teacher completed a brief survey. Teachers first reported the amount of English and Spanish used in classroom instruction. They then indicated each child's ethnic/ linguistic background.

Principal survey After testing in a school was completed, the principal was contacted by phone and asked about his/her policy regarding the assignment of students to classes in Kindergarten, First and Second Grade classrooms. Questions included: (a) the percentage of White/Anglo children assigned to classrooms on the basis of preferences expressed by their parents; (b) the percentage of Spanishspeaking children assigned to classrooms on the basis of preferences expressed by their parents; and (c) the degree to which these 'special' assignments based on parental preference had to do with preference for bilingual versus English-only instruction.
Responses to this survey allowed us to evaluate the degree to which parental preference might represent a meaningful confound. Across the five schools, principals' estimates of White/ Anglo children placed in classrooms on the basis of parental preference ranged from $0 \%$ to $30 \%$. In addition, principals who did make some special placements indicated that between $30 \%$ and $50 \%$ of these were for reasons other than language of instruction. Thus, even in the school with the highest degree of parental influence, only approximately two children per classroom were there because of parental preference for a particular language program. Thus, parental selection appears to play a minimal role in the distribution of children across classroom type. ${ }^{5}$

\section{Results}

\section{Analytic strategy}

Much of the interest in understanding children's intergroup attitudes involves attitudes at the negative end of the spectrum-that is, attitudes that can be considered 'prejudice'. This raises the question: 'At what point can we call a child's pattern of preferences "prejudice”?' (see Aboud, 1987; Nesdale, 2001). One response has been to compare children's appraisals of and preferences for ingroup members versus outgroup members. The larger the difference between these two appraisals/preferences, the more negative the intergroup attitude.

However, this approach presents three problems. First, under some circumstances, some preferential evaluation of the ingroup may be adaptive and appropriate (see Wright \& Taylor, 1995). Second, difference scores ignore the absolute level of each evaluation. For example, consider Child A, who describes ingroup targets as positive in six of six trials and outgroup targets as positive in three of six trials. This child has a difference score of 3 , a relatively large ingroup preference. Child B, who describes ingroup targets as positive in three of six trials and outgroup targets as positive in one of six trials, has a difference score of 2. Using only difference scores, Child B is seen to have more positive intergroup attitudes than is Child A. 
However, in absolute terms Child B has clearly rated the outgroup lower than Child A. The question of which child is more prejudiced (or whether either should be labeled as prejudiced) is not easily answered. Third, there are good reasons to believe that positive evaluation of the ingroup and negative evaluations of the outgroup may represent related but distinct psychological processes (see Brewer, 1999).

Our analytic strategy attempts to address these issues by reporting both absolute values and comparisons of ingroup and outgroup evaluations and preference using a repeated measures design. Additional analyses are also performed to isolate subgroups of children who demonstrate complete rejection of all outgroup members (see Katz, Sohn, \& Zalk, 1975) and/or demonstrate no bias in evaluations of and preferences for the ingroup and the outgroup. Complete rejection of the outgroup might be demonstrative of 'prejudice', while equal preferences for ingroup and outgroup members seems to represent a 'non-prejudice' pattern of response. Comparing the size of these two subgroups across different classroom contexts provides an additional test of the relative impact of bilingual and English-only instruction on intergroup attitudes.

\section{Preliminary analyses}

Accuracy in identifying targets To determine whether the children understood the task and were able to follow the tester's instructions, we examined their accuracy in sorting the target photos on the basis of gender. Of 351 children, 28 failed to identify all eight target photos correctly by gender. Of these, 27 children mislabeled one photo, and one child mislabeled two photos. Thus, it appears that children generally understood the task and were able to follow the directions. The children making errors were relatively equally distributed across the three types of classes (13 in White E-O classes, 8 in the Mixed E-O classes, 7 in the Bilingual classes).

Gender effects Children's scores on ingroup/ outgroup evaluation, friendship preferences, and perceived similarity were analyzed using 2
(Participant Gender) $\times 3$ (Type of Classroom) $\times 2$ (Ethnicity of Target) mixed analyses of variance. No significant main or interaction effects involving gender emerged, and thus gender was dropped from subsequent analyses.

Grade effects Children's scores on ingroup/ outgroup evaluation, friendship preferences, and perceived similarity were initially examined using 3 (Grade) $\times 3$ (Type of Classroom) $\times 2$ (Ethnicity of Target) mixed analysis of variance (ANOVA). The only significant effects involving grade were main effects of grade for friendship preference and perceived similarity, such that kindergarteners selected more friends and saw more targets as similar to them than did children in Grades 1 and 2-who do not differ significantly on either of these measures. No significant two-way or three-way interactions emerged and grade was dropped from subsequent analyses.

\section{Evaluations, friendship preferences, and perceived similarity to the self}

The 3 (Type of Classroom) $\times 2$ (Ethnicity of Target) mixed ANOVAS were performed twice, first with child as the unit of analysis and then with classroom as the unit of analysis. Type of Classroom (White E-O, Mixed E-O, Bilingual) was a between-subjects factor, and Ethnicity of Target (White, Latino) was a within-subjects factor.

Child as unit of analysis The analysis for Evaluations supported Hypothesis 1, yielding a significant main effect of Ethnicity of Target $\left(F(1,348)=48.58, p<.001, \eta^{2}=.12\right)$, indicating a general bias toward White $(71 \%)$ over Latino $(63 \%)$ targets. A significant two-way interaction also emerged $\left(F(2,348)=6.35, p=.002, \eta^{2}=\right.$ .03) (see Figure 1). Simple effects tests indicated no significant differences in evaluations of White targets among the three types of classrooms $\left(F(2,348)=0.64, p=.53, \eta^{2}<.001\right)$, but a significant difference in evaluations of Latino targets among the three types of classrooms $\left(F(2,348)=5.08, p=.007, \eta^{2}=.03\right)$. Consistent with Hypothesis 2a, pairwise comparisons revealed that children in both Bilingual classes 
$\left(F(2,348)=8.54, p=.004, \eta^{2}=.03\right)$ and Mixed E-O classes $\left(F(2,348)=4.93, p=.03, \eta^{2}=.02\right)$ evaluated Latinos significantly more positively than children in the White E-O classes. However, the differences in evaluations of Latino targets between children in Bilingual and Mixed E-O classes was not significant, thus failing to provide support of Hypothesis $3 a$.

The analysis for Friendship Preference also supported Hypothesis 1, yielding a significant main effect of Ethnicity of Target $(F(1,348)=85.94$, $\left.p<.001, \eta^{2}=.20\right)$, indicating a general preference for Whites $(46 \%)$ over Latinos $(30 \%)$ as friends. The main effect of Type of Classroom $\left(F(2,348)=4.51, p=.01, \eta^{2}=.02\right)$ and the twoway interaction $\left(F(2,348)=7.50, p=.001, \eta^{2}=\right.$ .04 ) were also significant (see Figure 2 ). Simple effects tests indicated no significant differences among the three types of classrooms for selection of Whites as friends $(F(2,348)=1.87, p=$ $\left..16, \eta^{2}<.01\right)$ but significant differences among the types of classrooms for selection of Latinos $\left(F(2,348)=8.23, p<.001, \eta^{2}=.04\right)$. Pairwise comparisons revealed partial support for Hypothesis 2b, as children in Bilingual classes were more likely to select Latino friends than those in White E-O classes $(F(2,348)=14.88$, $\left.p>.001, \eta^{2}=.05\right)$, yet children in Mixed E-O and White E-O classes did not differ $(F<1.0)$. Additionally, Hypothesis $3 b$ was supported, with children in Bilingual classes selecting more Latino targets as friends than those in Mixed E-O classes $\left(F(2,348)=5.54, p=.02, \eta^{2}=.03\right)$.

The analysis for Perceived Similarity also supported Hypothesis 1, with a significant main effect of Ethnicity of Target $(F(1,348)=142.48$, $\left.p<.001, \eta^{2}=.31\right)$. White children generally selected more Whites $(38 \%)$ over Latinos $(17 \%)$ as similar to the self. The main effect of Type of Classroom $(F(2,348)=22.88$, $p<.001, \eta^{2}=.12$ ) was also significant. Post hoc comparisons ${ }^{6}$ revealed that children in Bilingual classes selected significantly more targets as like self $(38 \%)$ than children in either Mixed E-O classes $(21 \%)$ or White E-O classes $(23 \%)$. The interaction approached statistical significance

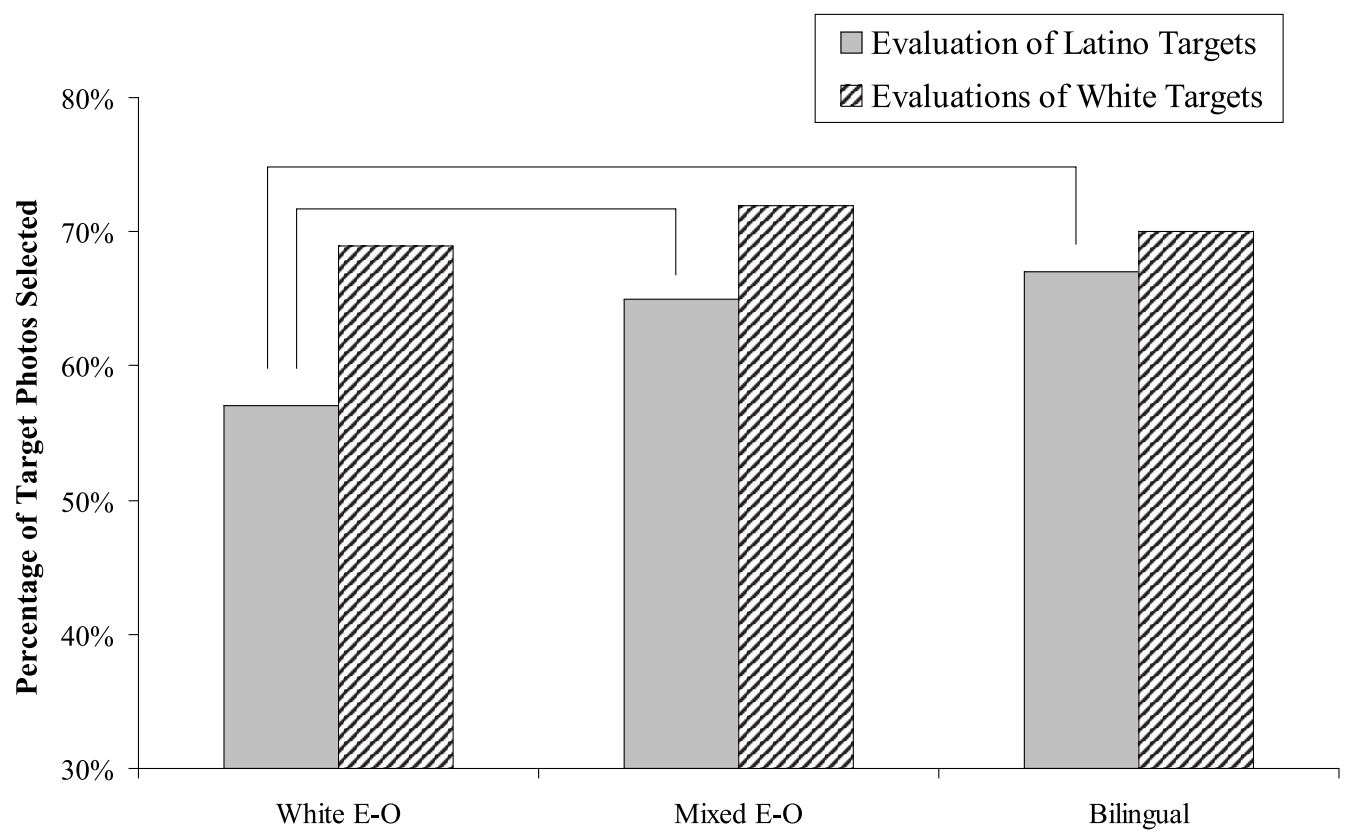

Type of Classroom

Figure 1. Evaluations of Latino and White targets by White children in three different types of classrooms. 
$\left(F(2,348)=2.46, p=.10, \eta^{2}=.02\right)$ (see Figure 3 ), and the pattern of results is consistent with those found for Friendship Preferences. Partially supporting Hypothesis $2 c$ and fully supporting Hypothesis $3 c$, children in Bilingual classes selected more Latino targets as similar to themselves than children in either the Mixed E-O classes $\left(F(2,348)=17.03, p<.001, \eta^{2}=.08\right)$ or children in the White E-O classes $(F(2,348)=$ $\left.28.37, p<.001, \eta^{2}=.09\right)$. All other comparisons were not significant.

Classroom as unit of analysis The analysis for Evaluations supported Hypothesis 1, yielding a significant main effect of Ethnicity of Target $\left(F(1,35)=18.37, p<.001, \eta^{2}=.34\right)$. White children demonstrated a general bias toward White $(71 \%)$ over Latino (63\%) targets. A significant two-way interaction also emerged $(F(2$, $\left.35)=4.00, p=.03, \eta^{2}=.18\right)$. Simple effects tests indicated that the pattern of means for this interaction were identical to those found in the analyses using children as the unit of analysis. There were no significant differences among the three types of classes for evaluations of Whites $(F(2,35)=0.002, p=.99)$. However, pairwise comparisons showed that children in Bilingual classes evaluated Latino targets significantly more positively $(70 \%)$ than children in White E-O classes $(61 \%)(F(2,35)=6.19, p=$ $\left..021, \eta^{2}=.20\right)$ and the difference between children in Bilingual $(70 \%)$ and Mixed E-O classes $(64 \%)$ approached significance $(F(2$, $\left.35)=2.85, p=.10, \eta^{2}=.05\right)$.

The analysis for Friendship Preference also supported Hypothesis 1, yielding a significant main effect of Ethnicity of Target $(F(1,35)=45.59$, $\left.p<.001, \eta^{2}=.56\right)$ such that the children showed a general preference for Whites $(47 \%)$ over Latinos (35\%). The main effect for Type of Classroom was also significant $(F(2,35)=5.07$, $\left.p=.01, \eta^{2}=.22\right)$ and although the two-way interaction did not reach traditional significance levels $\left(F(2,35)=2.11, p=.12, \eta^{2}=.09\right)$,

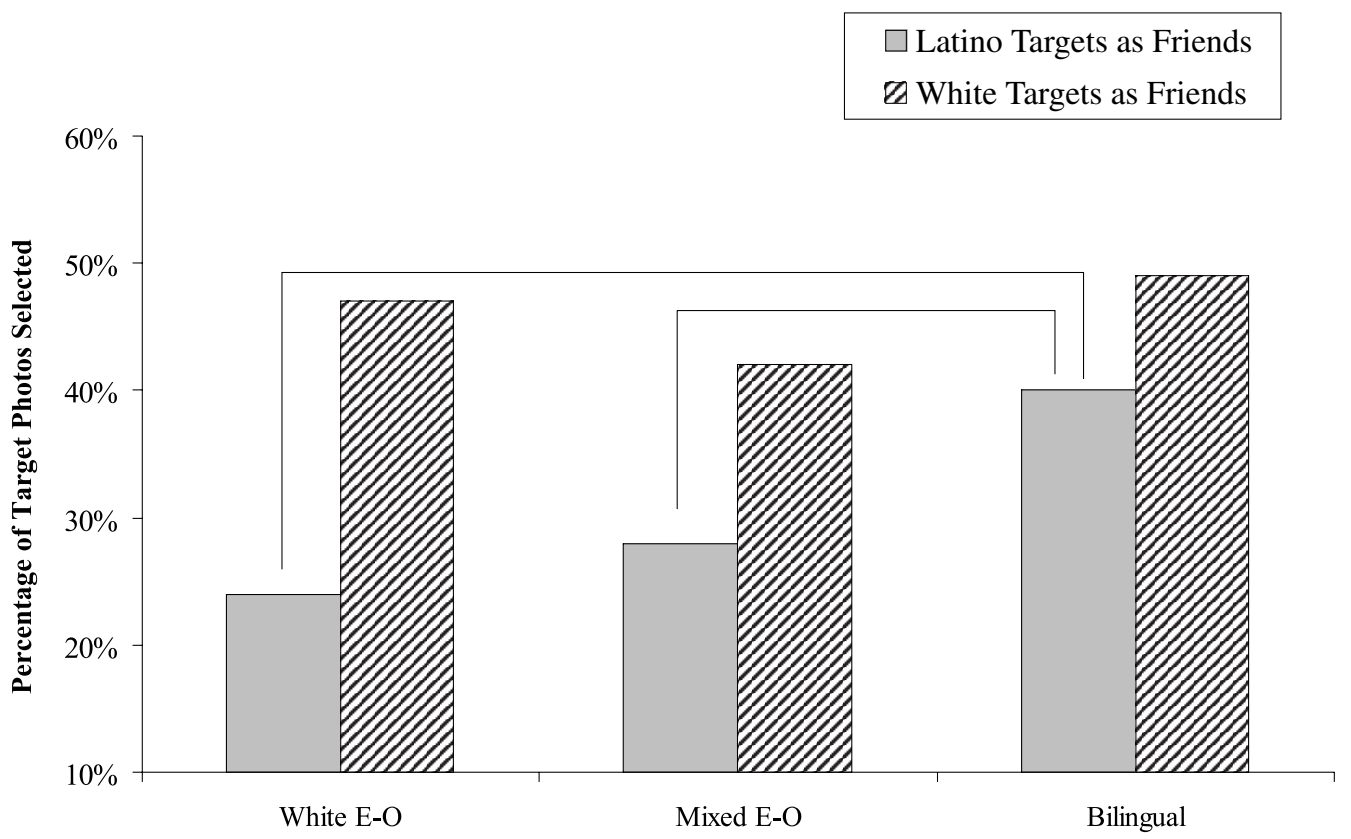

Type of Classroom

Figure 2. Friendship preferences for Latino and White targets by White children in three different types of classrooms. 


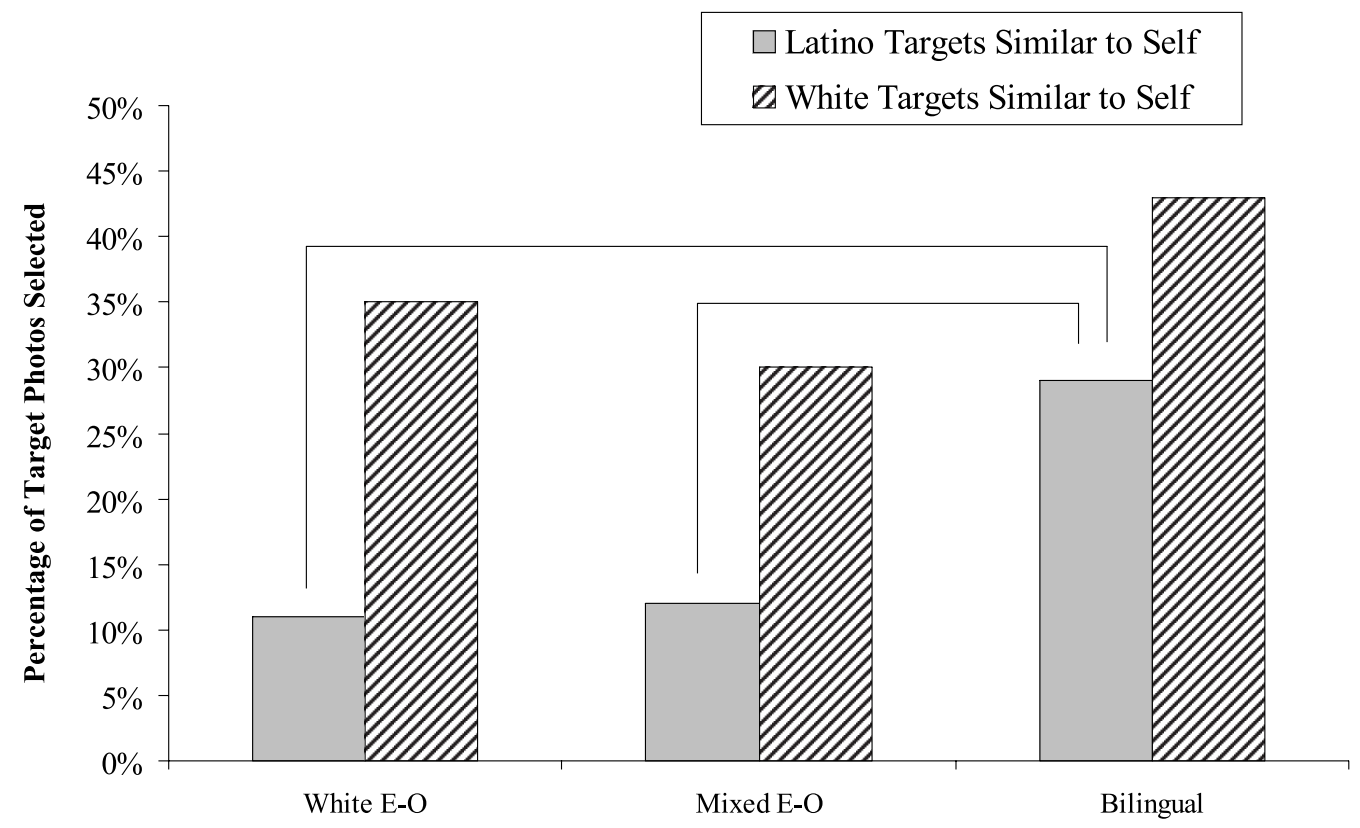

Type of Classroom

Figure 3. Perceived similarity of Latino and White targets to self by White children in three different types of classrooms.

simple effects tests and pairwise comparisons demonstrated a pattern of responses consistent with those found using child as the unit of analysis. There were no differences across the three classroom types in the selection of White friends $(F(2,35)=2.24, p=.12)$, while there were significant differences in the selection of Latino friends $\left(F(2,35)=5.85, p<.01, \eta^{2}=25\right)$. Consistent with Hypotheses $2 b$ and $3 b$, pairwise comparisons revealed those in Bilingual classes (43\%) selected significantly more Latino friends than those in Mixed E-O classes $(31 \%)(F(2,35)$ $\left.=5.98, p=.02, \eta^{2}=.18\right)$ and White E-O classes $(27 \%)\left(F(2,35)=8.86, p=.007, \eta^{2}=.27\right)$.

The analysis for Perceived Similarity yielded support for Hypothesis 1, with a significant main effect of Ethnicity of Target $(F(1,35)=53.56$, $\left.p<.001, \eta^{2}=.60\right)$. Children generally perceived more White targets as like themselves $(M=$ $37 \%)$ than Latino targets $(M=20 \%)$. The main effect of Type of Classroom was also significant $\left(F(2,35)=6.63, p=.004, \eta^{2}=.27\right)$, such that children in Bilingual classes $(M=39 \%)$ selected more targets from both groups as similar to self than children in either Mixed E-O classes $(M=$ $24 \%)$ or White E-O classes $(M=23 \%)$. The interaction effect was not significant $(F(1,35)=$ $\left.0.02, p=.95, \eta^{2}<.001\right)$, thus offering no direct support for Hypotheses $2 c$ or $3 c$ in this analysis.

\section{Examining subgroups of children: No ingroup preference and complete outgroup rejection}

Additional analyses were conducted on two subgroups of particular interest: (a) children demonstrating complete rejection of Latino targets, and (b) those who demonstrated no preference for Whites over Latinos. Friendship preferences and perceived similarity measures were used to define these subgroups, with one subgroup including children who selected only Whites as potential friends (or as similar to self), while the other subgroup included children who selected an equal number of Whites and Latinos as friends (or as similar to self). 
The distributions of these subgroups across the classroom types were compared using child as the unit of analysis. ${ }^{7}$

Friendship preferences Table 1 presents the percentages of children in each type of classroom who: (a) chose only Whites as friends; or (b) chose equal numbers of Whites and Latinos as friends. The $2 \times 3$ chi-square was significant $\left(\chi^{2}(2,230)=17.29, p<.001\right)$. Consistent with the essence of Hypotheses $2 b$ and $3 b$, the percentage of children selecting only Whites was more than twice as high in White E-O and Mixed E-O classes than in Bilingual classes. Also, nearly half of the children in Bilingual classes chose equal numbers of Whites and Latinos, while only one third in Mixed E-O and slightly more than one quarter in White E-O classes chose equal numbers of Whites and Latinos.

Perceived similarity Table 2 presents the percentages of children in each type of classroom who: (a) chose only Whites as similar to self; or (b) chose equal numbers of Whites and Latinos as similar to self. The $2 \times 3$ chi-square was significant $\left(\chi^{2}(2,265)=8.53, p<.01\right)$. Consistent with the essence of Hypotheses $2 c$, and $3 c$, the percentage of children selecting only Whites as similar to self was higher in White E-O and Mixed E-O classes than in Bilingual classes. Differences between classroom types were smaller for the percentage of children selecting equal numbers of Latinos and Whites, but the pattern was in the predicted direction.

\section{Self-evaluation and type of classroom environment}

Using child as the unit of analysis, a one-way ANOVA compared self-evaluations for children in each of the three types of classrooms. This analysis yielded no significant differences $(F(2$, $\left.353)=0.95, p=.39, \eta^{2}=.005\right)$, with most of the children in all three groups selecting their own photograph in response to all or most of the positive evaluation items (94\% for children in White E-O classes, $91 \%$ for children in Mixed E-O classes, and $92 \%$ for children in Bilingual classes).

\section{Discussion}

Consistent with Hypothesis 1 and previous findings (see Aboud, 1988), White children showed a preferential bias toward ingroup over outgroup

Table 1. Percentage and numbers of White children who chose only Whites or who chose equal numbers of Whites and Latinos as potential friends by type of classroom

\begin{tabular}{lcc}
\hline Type of classroom & Only White targets & Equal numbers of White/Latino targets \\
\hline White E-O & $38.7 \%$ & $28.2 \%$ \\
$(n=163)$ & $(n=63)$ & $(n=45)$ \\
Mixed E-O & $36.3 \%$ & $33.8 \%$ \\
$(n=80)$ & $(n=29)$ & $(n=27)$ \\
Bilingual & $16.8 \%$ & $46.0 \%$ \\
$(n=113)$ & $(n=19)$ & $(n=52)$ \\
\hline
\end{tabular}

Table 2. Percentages of White children who chose only Whites or equal numbers of Whites and Latinos as similar to themselves by type of classroom

\begin{tabular}{lcc}
\hline Type of classroom & Only White targets & Equal numbers of White/Latino targets \\
\hline White E-O & $58.3 \%$ & $23.3 \%$ \\
$(n=163)$ & $(n=95)$ & $(n=38)$ \\
Mixed E-O & $47.5 \%$ & $28.8 \%$ \\
$(n=80)$ & $(n=38)$ & $(n=23)$ \\
Bilingual & $34.5 \%$ & $32.7 \%$ \\
$(n=113)$ & $(n=39)$ & $(n=37)$ \\
\hline
\end{tabular}


targets. They evaluated White targets more positively than Latino targets, selected more White than Latino targets as potential friends, and were more likely to see Whites than Latinos as similar to themselves. However, as predicted, classroom environment moderated the strength of these biases. Overall, findings across the three measures (evaluation, friendship preference, and perceived similarity) support the prediction that bilingual instruction can contribute to more positive perceptions of the ethnolinguistic outgroup than English-only instruction. In addition, this greater positivity toward the outgroup occurs with no loss in positivity toward the White ingroup.

Moreover, these results clearly suggest that the positive effect of bilingual instruction is not simply the result of a more integrated classroom. Greater proportions of Latino classmates in English-only classes corresponded with more positive evaluations of Latinos, but not with greater preferences for Latinos as friends or perceiving more Latinos as similar to self. Instead, only bilingual instruction was associated with a greater tendency to select Latino targets as friends and greater perceptions of Latino targets as similar to the self. Thus, while ethnically balanced classes can contribute to positive intergroup attitudes, it appears that language of instruction has an additional positive impact on children's orientations toward members of an ethnolinguistic outgroup.

Also noteworthy is that the children are reporting evaluations, friendship preferences, and perceived similarity in response to photos of children that they have never seen before. Thus, we can conclude that bilingual instruction is associated with more positive orientations toward Latino children generally, and not just the specific Latino children with whom they have contact. Most contact research in educational settings has focused on attitudes toward one's classmates, rather than generalized attitudes (see Schofield, 1995). While achieving harmonious intergroup relations within the immediate contact situation is a valuable goal, only generalized positive attitudes will improve interactions with new outgroup members in new contact situations (see Brown
\& Hewstone, 2005; Hewstone \& Brown, 1986; Rothbart \& John, 1985). Thus, the present findings are particularly important, in that they show that the positive outgroup orientation learned in bilingual classes can generalize to the outgroup as a whole.

Moreover, the more positive outgroup orientation found among White children in bilingual classes did not come at the expense of the children's evaluations of themselves. Children gave very positive self-evaluations, which did not vary in relation to the language of instruction or representations of Latino children in the classroom. Thus, the more positive intergroup attitudes associated with bilingual instruction comes without any associated negative impact on children's evaluations of themselves or their own group.

Our findings also complement a number of central themes that have been stressed in recent theory and research on intergroup contact. Specifically, the results suggest that bilingual instruction may foster the type of equal status, authority supported, cooperative contact that encourages positive intergroup attitudes (see Allport, 1954; Pettigrew \& Tropp, 2000), and this is accomplished in a context where ethnic group membership remains salient (see Brown \& Hewstone, 2005). The results concerning children's friendship preferences also provide more direct support for the potential role of friendship in these intergroup contact effects (Wright et al., 2005; Pettigrew, 1997; Wright et al., 1997). Indeed, it may be that children in bilingual classes have been particularly successful in developing friendly relationships with Latino classmates, such that these friendship experiences account for the more general positive attitudes toward Latino targets.

Additionally, though we have focused on the experiences of White children, we might also consider the significance of our findings for the educational experiences of minority language students. Being the target of prejudice and bias can have a number of negative effects (see Swim \& Stangor, 1998), and minority language children will likely benefit from an environment in which their classmates hold them and their groups in high esteem (Berry \& Williams, 
2004). Moreover, the positive intergroup attitudes of their White classmates might have an impact on minority language speakers' acquisition of English. There is evidence that motivation to learn a second language, success in learning that language, and involvement in the educational context are all influenced by the quality of one's interactions with members of the target language group (see Gardner \& Clément, 1990). Furthermore, Genesee et al. (1983) have shown that students' expectations of support from the target language group were significantly related to various measures of second language use, proficiency, and willingness to affiliate with members of the target language group (see also Clément \& Kruidenier, 1985). Finally, there is also evidence that having the opportunity to develop friendships with Whites can be an important predictor of subsequent success for minority students (Braddock, 1985). Thus, improving the intergroup attitudes of White students may in turn have important implications for the classroom experiences and success of minority language children.

\section{Conclusions}

The extensive debates over bilingual education have generally overlooked how the language of instruction can impact intergroup attitudes. At the same time, research on intergroup attitudes and contact between groups has largely ignored the role of language use in these intergroup processes. This research links these areas of investigation and extends discussions of bilingual instruction beyond issues of academic achievement and language proficiency, by focusing on the intergroup implications of classroom language use.

Language is used to communicate and sharing a language certainly aids in the development of cross-group relationships, but the use of a language communicates important cues about who is valued and thus how we should expect crossgroup interactions to progress. Thus, while use of a minority language in the classroom might enhance the possibility that White Englishspeaking children would grow to learn the language of their minority classmates, the more important consequence, perhaps, is that instruction in the minority language structures the classroom context to improve the quality of the intergroup contact. Indeed, language is not only a marker of group differences but also is a tool that can be used to diminish (or strengthen) status inequalities, enhance (or undermine) interdependence, and demonstrate authority support (or lack thereof) for intergroup contact.

Results from this study show important differences in the attitudes of White children in English-only classes and those receiving bilingual instruction. While part of these differences may be accounted for by the greater representation of Latino children in bilingual classes, contact alone does not produce the pattern of positive attitudes found among White children who also receive consistent exposure to instruction in the Spanish language. Overall, these results suggest that bilingual instruction may have positive effects on the generalized intergroup attitudes of White children, supporting the claim that recent efforts to dismantle bilingual education may represent a serious backward step in the struggle to improve interethnic relations in our schools and our society.

\section{Notes}

1. To avoid the many difficulties associated with defining 'bilingual education' and attempting to match actual classroom practices with varied models of bilingual education (see Brisk, 1998), we will use the term 'bilingual instruction'. Here, bilingual instruction is meant to describe a more general classroom context in which a significant amount of instruction is provided in a language other than English. We compare this to 'English-only instruction' where English is the exclusive (or near exclusive) language of instruction. In the present research, bilingual instruction is operationalized as a classroom in which the teacher reports that between $30 \%$ and $60 \%$ of the classroom instruction is provided in Spanish.

2. Lambert, Genesee, and their colleagues have investigated the ethnic attitudes of 
English-speaking Canadian children in French immersion programs and found fairly consistently that French immersion education has a positive impact on attitudes toward Francophones (e.g. Genesee, 1987; Lambert \& Tucker, 1972). However, these programs involve classrooms and schools that are almost entirely made of native English speakers who are instructed entirely in French. This context differs substantially from the context being considered here in that the French immersion context often does not involve direct intergroup contact across linguistic groups and instruction in both languages.

3. More than 400 Latino children were also tested. Data from these children are presented elsewhere (see Tropp \& Wright, 2003).

4. Approximately three-quarters of the photographs were taken at schools other than those used in the present study. The remaining photographs were taken at the rural school and the two packets (of six) containing these pictures were not used at that school.

5. In addition, we performed a number of analyses comparing patterns of results across the five different schools. These analyses showed surprising consistency across schools. Further, the school at which the principal indicated that parental preference played no part in the assignment of students to classes showed one of the strongest and most consistent effects across the three dependent measures. The school at which the principal indicated the largest amount of parental influence on children's classroom placement $(30 \%)$ fell in the middle of the group in terms of the consistency and strength of the predicted effects.

6. All post hoc comparisons use Newman-Kuels, $\alpha=.05$.

7. This analysis can only be done using child as the unit of analysis. However, given that most of the previous analyses showed that, despite the substantial loss in power associated with analyses at the level of classroom, most of the key effects remained significant at this level of analysis. This consistency should provide some additional confidence regarding the analyses in which child was used as the unit of analysis.

\section{Acknowledgments}

The authors would like to thank the principals and teachers who supported this work by allowing us access to their students. Also, we thank the many undergraduate students at the University of California, Santa Cruz, who provided invaluable assistance in the collection of these data: Anabel Knoche, Virginia Martinez, Nicole Seno, Lenna Gochoel, Brenda Abrego, Olona Dientz, Kristen Martinez-Pedersen, Ryah Lindemuth, Ana Quiran, Sonia Ramos, Pam Barnett, Carolina Camarena, Monica Curtis, and Roberta Romero. This research was supported in part by a research grant from the Social Sciences Division, University of California Santa Cruz and by a Regents Faculty Research Grant, University of California Santa Cruz.

\section{References}

Aboud, F. E. (1977). Interest in ethnic information: A cross-cultural developmental study. Canadian Journal of Behavioural Science, 9, 134-146.

Aboud, F. E. (1987). The development of ethnic self-identification and attitudes. In J. S. Phinney \& M. J. Rotheram (Eds.), Children's ethnic socialization: Pluralism and development (pp. 32-55). Newbury Park, CA: Sage.

Aboud, F. E. (1988). Children and prejudice. New York: Blackwell.

Aboud, F. E., \& Levy, S. R. (2000). Interventions to reduce prejudice and discrimination in children and adolescents. In S. Oskamp (Ed.), Reducing prejudice and discrimination (pp. 269-293). Mahwah, NJ: Erlbaum.

Aboud, F. E., Mendelson, M. J., \& Purdy, K. T. (2003). Cross-race peer relations and friendship quality. International Journal of Behavioral Development, 27, 165-173.

Allport, G. W. (1954). The nature of prejudice. Cambridge, MA: Addison-Wesley.

Aronson, E., \& Patnoe, S. (1997). The jigsaw classroom: Building cooperation in the classroom. New York: Longman.

Asher, S. R., \& Allen, V. L. (1969). Racial preference and social comparison processes. Journal of Social Issues, 25, 157-167.

Banks, J. A. (1995). Multicultural education and the modification of students' racial attitudes. In W. D. Hawley \& A. W. Jackson (Eds.), Towards a common destiny: Improving race and ethnic relations in America (pp. 315-339). San Francisco: Jossey-Bass.

Barker, V., Giles, H., Noels, K. A., Duck, J., Hecht, M., \& Clément, R. (2001). The English-only movement: A communication analysis of changing perceptions of language vitality. Journal of Communication, 51, 3-37.

Berry, R. S. Y., \& Williams, M. (2004). In at the deep 
end: Difficulties experienced by Hong Kong Chinese ESL learners at an independent school in the United Kingdom. Journal of Language and Social Psychology, 23, 118-134.

Braddock, J. H. (1985). School desegregation and black assimilation. Journal of Social Issues, 41, 9-22.

Brewer, M. B. (1999). The psychology of prejudice: Ingroup love or outgroup hate? Journal of Social Issues, 55, 429-444.

Brewer, M. B., \& Brown, R. J. (1998). Intergroup relations. In D. T. Gilbert, S. T. Fiske, \& G. Lindzey (Eds.), Handbook of social psychology (4th ed., pp. 554-594). Boston: McGraw-Hill.

Brewer, M. B., \& Miller, N. (1984). Beyond the contact hypothesis: Theoretical perspectives on desegregation. In N. Miller \& M. B. Brewer (Eds.), Groups in contact: The psychology of desegregation (pp. 281-302). New York: Academic.

Brown, R., \& Hewstone, M. (2005). An integrative theory of intergroup contact. In M. P. Zanna (Ed.) Advances in Experimental Social Psychology (Vol. 37, pp. 255-343). San Diego, CA: Elsevier Academic Press.

Brisk, M. (1998). Bilingual education: From compensatory to quality schooling. Mahwah, NJ: Erlbaum.

Clément, R., \& Kruidenier, B. G. (1985). Aptitude, attitude and motivation in second language proficiency: A test of Clément's model. Journal of Language and Social Psychology, 4, 21-37.

Cohen, E. G. (1980). Design and redesign of the desegregated school: Problems of status, power, and conflict. In W. G. Stephan \& J. R. Feagin (Eds.), School desegregation: Past, present and future (pp. 251-280). New York: Plenum.

Cole, M., \& Cole, S. R. (1993). The development of children (2nd ed.) New York: Freeman.

Corenblum, B., \& Wilson, A. E. (1982). Ethnic preference and identification among Canadian Indian and White children: Replication and extension. Canadian Journal of Behavioural Science, 14, 50-59.

Covington, M. V. (1989). Self-esteem and failure at school: Analysis and policy implications. In A. M. Mecca, N. J. Smelser, \& J. Vasconcellos (Eds.), The social importance of self-esteem (pp. 72-124). Berkeley, CA: University of California Press.

Crawford, J. (1989). Bilingual education: History, policies, theory, and practice. Trenton, NJ: Crane.

Cummins, J. (1989). Empowering minority students. Sacramento, CA: California Association for Bilingual Education.

Damico, S. B., Bell-Nathaniel, A., \& Green, C. (1981). Effects of school organizational structure on interracial friendships in middle schools. Journal of Educational Research, 74, 388-393.

Doyle, A. B., \& Aboud, F. E. (1995). A longitudinal study of White children's racial prejudice as a social-cognitive development. Merrill-Palmer Quarterly, 41, 209-228.

Edwards, J. R. (1977). Ethnic identity and bilingual education. In H. Giles (Ed.), Language, ethnicity, and intergroup relations (pp. 253-282). London: Academic Press.

Fehr, B. (1996). Friendship processes. Thousand Oaks, CA: Sage.

Foster, D. (1994). Racism and children's intergroup orientations: Their development and the question of psychological effects on minority group children. In A. Dawes \& D. Donald (Eds.), Childhood and adversity: Psychological perspectives from South African research (pp. 220-239). Cape Town: David Philip.

Gaertner S. L., \& Dovidio, J. F. (2000). Reducing intergroup bias: The common ingroup identity model. Philadelphia: Psychology Press.

Gardner, R. C., \& Clément, R. (1990). Social psychological perspectives on second language acquisition. In H. Giles \& W. P. Robinson (Eds.), Handbook of language and social psychology (pp. 495-517). Chichester, UK: Wiley.

Genesee, F. (1987). Learning through two languages: Studies of immersion and bilingual education. Cambridge, MA: Newbury House.

Genesee, F., \& Gándara, P. (1999). Bilingual education programs: A cross-national perspective. Journal of Social Issues, 55, 665-685.

Genesee, F., Rogers, P., \& Holobow, N. (1983). The social psychology of second language learning: Another point of view. Language Learning, 33, 209-224.

Giles, H., Bourhis, R. Y., \& Taylor, D. M. (1977) Towards a theory of language in intergroup relations. In H. Giles (Ed.), Language, ethnicity, and intergroup relation (pp. 307-348). London: Academic Press.

Greene, J. P. (1997). A meta-analysis of the Rossell and Baker review of bilingual education research. Bilingual Research Journal, 21, 103-121.

Gudykunst, W. B., \& Schmidt, K. L. (1987). Language and ethnic identity: An overview and prologue. Journal of Language and Social Psychology, 6, 157-170.

Hakuta, K. (1986). Mirror of language: The debate on bilingualism. New York: Basic Books.

Hakuta, K., Butler, Y. G., \& Witt, D. (2000). How long does it take English learners to attain proficiency? (Policy Report 2000-1). Santa Barbara, CA: The 
University of California Linguistic Minority Research Institute.

Harter, S. (1986). Processes underlying the construction, maintenance, and enhancement of the self-concept of children. In J. Suls \& A. Greenwald (Eds.), Psychological perspectives on the self (pp. 136-182). Hillsdale, NJ: Erlbaum.

Heller, M. (1987). The role of language in the formation of ethnic identity. In J. S. Phinney \& M. J. Rotheram (Eds.), Children's ethnic socialization: Pluralism and development (pp. 180-200). Newbury Park, CA: Sage.

Hewstone, M., \& Brown, R. (1986). Contact is not enough: An intergroup perspective on the 'Contact Hypothesis'. In M. Hewstone \& R. Brown (Eds.), Contact and conflict in intergroup encounters (pp. 1-44). Oxford, UK: Basil Blackwell.

Johnson, D. W., Johnson, R., \& Maruyama, G. (1984). Goal interdependence and interpersonal attraction in heterogeneous classrooms: A meta-analysis. In N. Miller \& M. B. Brewer (Eds.), Groups in contact: The psychology of desegregation (pp. 187-212). New York: Academic Press.

Kagan, S. (1986). Cooperative learning and sociocultural factors in schooling. In Bilingual Education Office (Ed.), Beyond language: Social and cultural factors in schooling language minority students (pp. 231-298). Sacramento, CA: California State Department of Education.

Katz, P. A. (1983). Developmental foundations of gender and racial attitudes. In R. L. Leahy (Ed.), The child's construction of social inequality (pp. 41-78). New York: Academic Press.

Katz, P. A., Sohn, M., \& Zalk, S. R. (1975). Perceptual concomitants of racial attitudes in urban grade-school children. Developmental Psychology, 11, 135-144.

Khmelkov, V. T., \& Hallinan, M. T. (1999). Organizational effects on race relations in schools. Journal of Social Issues, 55, 627-645.

Kistner, J., Metzler, A., Gatlin, D., \& Risi, S. (1993). Classroom racial proportions and children's peer relations: Race and gender effects. Journal of Educational Psychology, 85, 446-452.

Lambert, W. E., \& Cazabon, M. (1994). Students'views of the Amigos program (Research Report No. 11). Santa Cruz, CA: University of California, National Center for Research on Cultural Diversity and Second Language Learning.

Lambert, W. E., Genesee, F., Holobow, N. E., \& Chartrand, L. (1993). Bilingual education for majority English-speaking children. European Journal of Psychology of Education, 8, 3-22.

Lambert, W. E., \& Tucker, G. R. (1972). Bilingual education of children: The St. Lambert experiment. Rowley, MA: Newbury House.

Lindholm, K. J. (1994). Promoting positive cross-cultural attitudes and perceived competence in culturally and linguistically diverse classrooms. In R. A. Devillar, C. J. Faltis, \& J. P. Cummins (Eds.), Cultural diversity in schools: From rhetoric to practice (pp. 189-206). Albany, NY: State University of New York Press.

McLaughlin-Volpe, T., Aron, A., Wright, S. C., \& Reis, H. T. (2000). Intergroup social interactions and intergroup prejudice: Quantity versus quality. Manuscript under review.

Miller, N., \& Brewer, M. B. (1984). Groups in contact: The psychology of desegregation. New York: Academic Press.

Nesdale, D. (2001). Language and the development of children's ethnic prejudice. Journal of Language and Social Psychology, 20, 90-110.

Noels, K. A., Pon, G., \& Clément, R. (1996). Language, identity, and adjustment: The role of linguistic self-confidence in the acculturation process. Journal of Language and Social Psychology, 15, 246-264.

Parker, L. L. (1978). Current perspectives. In Center for Applied Linguistics (Ed.), Bilingual education: Current perspectives (pp. 1-62). Arlington, VA: Center for Applied Linguistics.

Pettigrew, T. F. (1997). Generalized intergroup contact effects on prejudice. Personality and Social Psychology Bulletin, 23, 173-185.

Pettigrew, T. F. (1998). Intergroup contact theory. Annual Review of Psychology, 49, 65-85.

Pettigrew, T. F., \& Tropp, L. (2000). Does intergroup contact reduce prejudice? Recent meta-analytic findings. In S. Oskamp (Ed.), Reducing prejudice and discrimination: Social psychological perspectives (pp. 93-114). Mahwah, NJ: Erlbaum.

Pettigrew, T. F., \& Tropp, L. R. (in press). A meta-analytic test of intergroup contact theory. Manuscript under review. Journal of Personality and Social Psychology.

Ramsey, P. G. (1987). Young children's thinking about ethnic differences. In J. S. Phinney \& M. J. Rotheram (Eds.), Children's ethnic socialization: Pluralism and development (pp. 56-72). Newbury Park, CA: Sage.

Rothbart, M., \& John, O. P. (1985). Social categorization and behavioral episodes: A cognitive analysis of the effects of intergroup contact. Journal of Social Issues, 41, 81-104.

Schofield, J. W. (1989). Black and White in school: Trust, tension, or tolerance? New York: Teachers College Press. 
Schofield, J. W. (1995). Promoting positive intergroup relations in school settings. In W. D. Hawley \& A. W. Jackson (Eds.), Towards a common destiny: Improving race and ethnic relations in America (pp. 257-289). San Francisco: Jossey-Bass.

Schofield, J. W., \& Sagar, H. A. (1977). Peer interaction patterns in an integrated middle school. Sociometry, 40, 130-138.

Slavin, R. E., \& Cheung, A. (1999). Effective reading programs for English language learners: A best evidence synthesis (Report No. 66). Baltimore, MD: Johns Hopkins University, Center for Research on the Education of Students Placed At Risk.

Slavin, R. E., \& Cooper, R. (1999). Improving intergroup relations: Lessons learned from cooperative learning programs. Journal of Social Issues, 55, 647-663.

Stephan, W. G., \& Rosenfield, D. (1978). Effects of desegregation on racial attitudes. Journal of Personality and Social Psychology, 36, 795-804.

Sue, S., \& Padilla, A. (1986). Ethnic minority issues in the United States: Challenges for the educational system. In Bilingual Education Office (Ed.), Beyond language: Social and cultural factors in schooling language minority students (pp. 35-72).

Sacramento, CA: California State Department of Education.

Swim, J. K., \& Stangor, C. (Eds.). (1998). Prejudice: The target's perspectives. San Diego, CA: Academic Press.

Tajfel, H. (1978). Differentiation between social groups: Studies in the social psychology of intergroup relations. London: Academic Press.

Tropp, L. R., \& Wright, S. C. (2003). Examining egocentrism and ethnocentrism among young Latino and White children. Self and Identity, 2, 203-221.

Turner, J. C., Hogg, M. A., Oakes, P. J., Reicher, S. D., \& Wetherell, M. S. (1987). Rediscovering the social group: A self-categorization theory. New York: Basil Blackwell.

Van Hook, J., \& Fix, M. (2000). A profile of the immigrant student population. In J. Ruiz de Velasco, M. Fix, \& B. Chu Clewell (Eds.), Overlooked and underserved: Immigrant students in U.S. secondary schools. Washington, DC: Urban Institute.

Weiland, A., \& Coughlin, R. (1979). Self-identification and preferences: A comparison of White and Mexican-American first- and third-graders. Journal of Cross-Cultural Psychology, 10, 356-365.

Williams, J., \& Morland, J. (1976). Race, color, and the young child. Chapel Hill, NC: University of North Carolina Press.
Willig, A. C. (1985). A meta-analysis of selected studies on the effectiveness of bilingual education. Review of Educational Research, 55, 269-317.

Wong-Fillmore, L., \& Valdez, C. (1986). Teaching bilingual learners. In M. C. Wittrock (Ed.), Handbook of research on teaching (3rd ed., pp. 648-685) New York: Macmillan.

Wright, S. C., Aron, A., McLaughlin-Volpe, T., \& Ropp, S. A. (1997). The extended contact effect: Knowledge of cross-group friendships and prejudice. Journal of Personality and Social Psychology, 73, 73-90.

Wright, S. C., Aron, A., \& Tropp, L. R. (2002). Including others (and groups) in the self: Self-expansion and intergroup relations. In J. P. Forgas \& K. D. Williams (Eds.), The social self: Cognitive, interpersonal and intergroup perspectives (pp. 343-363). Philadelphia: Psychology Press.

Wright, S. C., Brody, S. A., \& Aron, A. (2005). Intergroup contact: Still our best hope for improving intergroup relations. In C. Crandall \& M. Schaller (Eds.), Social psychology of prejudice: Historical perspectives (pp. 115-142). Seattle, WA; Lewinian Press.

Wright, S. C., \& Taylor, D. M. (1995). Identity and language of the classroom: Investigating the impact of heritage versus second language instruction on personal and collective self-esteem. Journal of Educational Psychology, 87, 241-252.

Wright, S. C., Taylor, D. M., \& Macarthur J. (2000). Subtractive bilingualism and the survival of the Inuit language: Heritage versus second language education. Journal of Educational Psychology, 92, 63-84.

Wright, S. C., \& Van Der Zande, C. C. (1999). Bicultural friends: When cross-group friendships cause improved intergroup attitudes. Paper presented at the Society for Experimental Social Psychology, St. Louis, MO.

Paper received 14 February 2004; revised version accepted 17 January 2005.

\section{Biographical notes}

STEPHEN C. WRIGHT is currently serving as associate professor of psychology and Canada Research Chair in Social Psychology at Simon Fraser University. He is also associate professor of psychology at the University of California, Santa Cruz. He received his $\mathrm{PhD}$ from McGill University in 1991. His research interests focus on intergroup relations, collective action, prejudice, prejudice reduction, and issues of minority language and 
culture. He has served as associate editor of Personality and Social Psychology Bulletin, and on the editorial boards of numerous scholarly journals. His work has been published in numerous book chapters and in articles in major social, educational, and cross-cultural psychology journals, and he is the co-author of Social Psychology in Cross-Cultural Perspective.

LINDA R. TROPP received her BA from Wellesley College and her $\mathrm{PhD}$ in social psychology from the University of California, Santa Cruz. She is currently an assistant professor of psychology at
Boston College and a member of the Governing Council of the Society for the Psychological Study of Social Issues. Her main research programs concern experiences with intergroup contact among minority and majority status groups, membership in and identification with social groups, and responses to prejudice and disadvantage among socially devalued groups. Her work has been published in numerous journal articles and book chapters, and she received the 2003 Gordon W. Allport Intergroup Relations Prize for her research on intergroup contact (in collaboration with Thomas F. Pettigrew). 